\title{
Knowledge, Attitude, and Practices Related to COVID-19 among Healthcare Personnel in a Tertiary Care Hospital in Nepal: A Cross-sectional Survey Basnet S, ${ }^{1}$ Dahal S, ${ }^{1}$ Tamrakar D, ${ }^{2}$ Shakya YR, ${ }^{3}$ Jacobson C, ${ }^{1,4}$ Shrestha J, ${ }^{5}$ Shrestha SK ${ }^{1}$
}

${ }^{1}$ Department of General Practice and Emergency Medicine,

${ }^{2}$ Department of Community Medicine,

${ }^{3}$ Department of General Surgery,

${ }^{4}$ Fulbright U.S. Student Program,

The United States Education Foundation.

Kathmandu 44600, Nepal.

${ }^{5}$ Department of Nursing,

Dhulikhel Hospital, Kathmandu University Hospital

Kathmandu University School of Medical Sciences,

Dhulikhel, Kavre, Nepal.

Corresponding Author

Samjhana Basnet

Department of General Practice and Emergency Medicine,

Dhulikhel Hospital, Kathmandu University Hospital Kathmandu University School of Medical Sciences, Dhulikhel, Kavre, Nepal.

E-mail: drbasnets@gmail.com

Citation

Basnet S, Dahal S, Tamrakar D, Shakya YR, Jacobson C, Shrestha J, et al. Knowledge, Attitude, and Practices Related to COVID-19 among Healthcare Personnel in a Tertiary Care Hospital in Nepal: A Cross-Sectional Survey. Kathmandu Univ Med J. 2020;COVID-19 Special Issue 70(2):21-8.

\begin{abstract}
Background

COVID-19 is significantly affecting the healthcare system globally. As a result, healthcare workers need to be updated on the best practices for the proper management of the disease.
\end{abstract}

\section{Objective}

The purpose of this study was to assess the knowledge, attitude, and practices (KAP) related to COVID-19 among healthcare personnel.

\section{Method}

This was a cross-sectional study conducted among medical personnel at Dhulikhel Hospital Kathmandu University Hospital using a semi-structured questionnaire on KAP related to COVID-19 from May $8^{\text {th }}$ to June $8^{\text {th }}, 2020$. We analyzed survey data by using descriptive statistics. Spearman rank correlation, chi-square test and binary logistic analysis were used to examine the association between sociodemographic characteristics with KAP related to COVID-19.

\section{Result}

Among 220 participants, the majority were nurses (60\%) followed by doctors (27.7\%), paramedics (10\%) and technicians (2.3\%). The results showed that $68.6 \%$ of healthcare personnel had a good knowledge with appropriate practices $(98.5 \%)$ and negative attitude (59.3\%). In the multivariate binary logistic analysis, the healthcare workers with the clinical experience level of one to five years (OR:.42, 95\% Cl:.19.96) and more than 5 years (OR: .16, 95\% Cl: .04-.63) were significantly associated with negative attitude. The confidence score for managing COVID-19 (OR:1.16, 95\% $\mathrm{Cl}: 1.02-1.34)$ was significantly associated with an optimistic attitude.

\section{Conclusion}

Healthcare workers are knowledgeable about COVID-19 and proactively practising to minimize the spread of infection but lack optimistic attitudes. Hence, the constantly updated educational programmes related to COVID-19 for targeted groups will contribute to improving healthcare workers' attitude and practices.

\section{KEY WORDS}

Awareness, COVID-19, Infectious disease 


\section{INTRODUCTION}

The novel coronavirus disease (COVID-19) caused by a new strain of coronavirus was declared as a pandemic by the World Health Organization (WHO) on 11 March 2020 and now is an unprecedented global issue. ${ }^{1}$ Nepal reported the first case of COVID-19 on 25 January 2019, and the first death due to COVID-19 on $16^{\text {th }}$ May 2020 in the Emergency Department of Dhulikhel Hospital. ${ }^{2-3}$

Worldwide, the major challenges lie in delivering proper care to COVID patients and to prevent the spread of infection among healthcare personnel and the general public. The proper preventive measures for COVID-19 infection have not been effectively implemented in all places and adherence to them is not consistent. ${ }^{4-6}$ Additionally, the implementation of new guidelines brings its own set of challenges related to the communication of the guidelines, availability of resources, access to equipment, the practice of use of equipment, simulation sessions and desire to participate. ${ }^{4,7}$ These factors are influenced by the knowledge, attitudes, and practices (KAP) of healthcare personnel (HCP) related to the disease and the new guidelines that are to be introduced to their routine work. ${ }^{7,8}$

Inadequate awareness, improper practices and negative attitudes can directly affect the patient's care and increase the risk of infection. ${ }^{9,10}$ There are limited studies that have documented how HCP in Nepal have adapted to new demands of healthcare and what areas need to be focused on for improvement. ${ }^{11,12}$ Hence, this study aims to assess the knowledge, attitudes, and practices regarding COVID-19 among HCP in a tertiary care hospital in Nepal.

\section{METHODS}

We conducted an institution based cross-sectional study in Dhulikhel Hospital, Kathmandu University Hospital from May $8^{\text {th }}$ to June $8^{\text {th }} 2020$. Health care personnel (physician, specialist, nurses, paramedics and technicians) who were assigned for duty for the care of suspected or confirmed COVID-19 and came to attend a training titled, "World Health Organization, Infection Prevention and Control (IPC) for Novel Coronavirus (COVID-19)" participated in the study. The convenience sampling method was used to enroll the participants.

The total number of HCP in the Hospital is 1257 (N). With an anticipated response rate of $20 \%$ (p) with a Confidence Interval of $95 \%$ and $5 \%$ (d) margin of error, Design effect (for cluster surveys-DEFF), the sample size is calculated as $206 .^{13}$

Sample size $n=[D E F F * N p \quad(1-p)] /\left[\left(d^{2} / Z^{2} 1-\alpha / 2 *(N-\right.\right.$ 1) $\left.+p^{*}(1-p)\right]$

In total, 220 participants took part in the survey. Informed and written consent was taken from the participants before filling the questionnaire of the study with emphasis on the confidentiality of personal data which will only be used for scientific work. Ethical approval was obtained from the Institutional Review Committee of Kathmandu University School of Medical Science Dhulikhel Hospital.

The initial draft of the questionnaire was created by the authors based on studies by Mohammed O. Nour et al. and AJ Alsahafi. ${ }^{14,15}$ Later, it was modified according to the most recently available information (until March 1) from the World Health Organization, Centers for Disease Control and Prevention and Nepal Ministry of Health, Health Emergency Operation Center. ${ }^{16-18}$

The questionnaire was reviewed by experts in the related fields and also a pilot study was conducted with 20 participants (4 from each randomly selected department of Dhulikhel Hospital, including all the HCP) to test the validity of the questionnaire and modifications were made after a series of group discussions. The data from the pilot study was removed from the final analysis.

The questionnaire was divided into 4 parts:

The first part consisted of demographic information like gender, age, education, clinical experience, designation, department and the respondent's confidence in handling COVID-19 cases.

The second part consisted of questions regarding basic and clinical microbiology of coronavirus for knowledge assessment ( $n=12$ questions).

The third consisted of questions about COVID-19 related practices ( $n=4$ questions). It addressed isolation of suspected cases, prevention of transmission, close contacts tracing, and use of masks.

The fourth part consisted of questions about healthcare workers' attitudes ( $n=10$ questions) towards COVID-19 prevention and management. It focused on infection control, patient care, and safety of health personnel and their family.

In questions with more than three options, 2 points for the complete right answer, 1 point for the partially correct answer, and 0 points for the wrong answer. In questions with yes, no, maybe/don't know as options, 1 point for the right answer and 0 points for the wrong answer.

The total knowledge, practice and attitude scores were ranged from 0 to 22,0 to 6 , and 0 to 10 respectively. Participants scoring $\geq 60 \%$ were considered to have good knowledge, good practice and positive attitudes of the total expected scores. ${ }^{19}$

Statistical analysis was carried out using the SPSS computer package version 20.0 (SPSS Inc., Chicago, IL, USA). The mean or median and standard deviation or interquartile range (IQR) were used as continuous variables and the frequency and percentages were used as categorical variables. The statistical methods were verified, assuming a significance 
level of $p<0.05$ and a highly significant level of $p<0.001$. The association of knowledge, attitudes, and practices with demographic characteristics and confidence of handling COVID-19 were measured using a chi-square test and spearman correlation. The binary logistic analysis(bivariate and multivariate) was performed to determine the influencing factors on healthcare workers KAP related to COVID-19.

\section{RESULTS}

\section{Sample Characteristics}

Of the total $260 \mathrm{HCP}, 220$ agreed to participate in the survey (response rate $=84.61 \%$ ). The majority of the respondents were female $(n=174,79.1 \%)$ and nurses $(n=132,60 \%)$ with the median age of 26 years (IQR:6). The age of the participants ranged from 19 to 50 years and the majority of them were under the age of 30 years. Most of the participants had 1 to 5 years of clinical experience $(n=140$, $63.6 \%)$. Fifty-two participants (23.6\%) had less than one year of experience, and 28 participants $(12.7 \%)$ had more than 5 years of experience. More than half of participants ( $n=141,64.1 \%$ ) had received a certificate level of education while bachelor and postgraduate education was attained by $20.9 \%(n=46)$ and $15 \%(n=33)$ respectively. Almost every department equally participated in the study and their sociodemographic characteristics are given in (Table 1).

\section{Sources of Knowledge about COVID-19}

The major source of knowledge was social media $(n=186)$. Among the participants, some were dependent on coworkers $(n=160)$ and others received information from radio/television $(n=125)$, website $(n=88)$, newspaper $(n=87)$ and neighbors $(n=57)$ respectively (Table 1$)$.

\section{Knowledge}

The overall median knowledge score was 15(IQR:4) ranging from 7 to 22. A score 14 or above was considered as "good" knowledge, and a score below 14 was considered as "poor" knowledge. About one third ( $n=69,31.4 \%$ ) of the respondents had poor knowledge and the remaining two thirds ( $n=151,68.6 \%)$ had good knowledge. The majority of participants provided correct answers for the questions name of the causative organism (84.8\%), disease manifestation in human being (96.8\%), an incubation period of coronavirus in human being $(80.5 \%)$, recovery from coronavirus infection in human being (98.6\%) and availability of vaccine $(90.7 \%)$. However, they did not report in-depth knowledge of coronaviruses such as the size of the coronavirus $(65.5 \%)$, sequence $(51.7 \%)$, identification or diagnosis (51.8\%), and mortality due to disease (52.4\%) (Table 2).

The chi-square test showed that participants in the postgraduate level (90.9\%) and bachelor level (84.8\%) achieved higher knowledge scores than the participants
Table 1. Sociodemographic characteristics of study participants ( $\mathrm{N}=\mathbf{2 2 0})$

\begin{tabular}{|c|c|}
\hline Variables & Frequency (\%) \\
\hline \multicolumn{2}{|l|}{ Age (years) } \\
\hline Median(IQR) & $26(6 \%)$ \\
\hline $19-30$ & $177(80.5 \%)$ \\
\hline $31-50$ & $43(19.5 \%)$ \\
\hline \multicolumn{2}{|l|}{ Gender } \\
\hline Male & $46(20.9 \%)$ \\
\hline Female & $174(79.1 \%)$ \\
\hline \multicolumn{2}{|l|}{ Occupation } \\
\hline Doctors & $61(27.7 \%)$ \\
\hline Nurses & $132(60 \%)$ \\
\hline Paramedics & $22(10 \%)$ \\
\hline Technician* & $5(2.3 \%)$ \\
\hline \multicolumn{2}{|l|}{ Clinical experience } \\
\hline Less than 1 year & $52(23.6 \%)$ \\
\hline $1-5$ years & $140(63.6 \%)$ \\
\hline$>5$ years & $28(12.7 \%)$ \\
\hline \multicolumn{2}{|l|}{ Level of Education } \\
\hline Certificate & $141(64.1 \%)$ \\
\hline Bachelor & $46(20.9 \%)$ \\
\hline Master & $3(15 \%)$ \\
\hline \multicolumn{2}{|l|}{ Source of Knowledge } \\
\hline Social media & $186(26.45 \%)$ \\
\hline Co-workers & $160(22.75 \%)$ \\
\hline Radio/Television & $125(17.78 \%)$ \\
\hline Newspaper & $87(12.37 \%)$ \\
\hline Neighbour & $57(8.1 \%)$ \\
\hline
\end{tabular}

with the certificate level of education (58.2\%) (Table 3). The odds of scoring a good knowledge score was higher among bachelors (OR: 4.01, Cl: 1.68-9.58) and masters (OR: 7.19, Cl: 2.10-24.69) level healthcare workers (Table 4). We also found that doctors (91.8\%) are more knowledgeable regarding COVID-19 than other professions of healthcare workers. The odds ratio for medical doctors (OR: $16.8, \mathrm{Cl}$ : 2.25-125.32) obtaining a good knowledge score was the highest among all the independent variables (Table 4).

\section{Attitude}

The overall median attitude score was 5 (IQR:2). A score 6 or above was considered as a "positive" attitude, and a score below 6 was considered a "negative" attitude. Within the sample, 87 respondents $(40.7 \%)$ had positive attitudes and 127 (59.3\%) had negative attitudes (Table $3)$. On average, the question with the highest number of negative responses $(n=206)$ was about the impact of the corona pandemic on Nepal's economy and about fear of family members becoming infected $(n=200)$. Additionally, healthcare workers $(n=176)$ responded that they were 
Table 2. Participant's response to knowledge attitude and practice questions

\begin{tabular}{|c|c|c|c|}
\hline \multirow{2}{*}{$\begin{array}{l}\text { Questions } \\
\text { Knowledge }\end{array}$} & \multicolumn{2}{|c|}{ Response $(\mathrm{N}=220)$} & \multirow[b]{2}{*}{$\begin{array}{l}\text { Right } \\
\text { Answers } \\
\mathrm{n}(\%)\end{array}$} \\
\hline & $\begin{array}{l}\text { Wrong } \\
\text { Answers } \\
\mathrm{n}(\%)\end{array}$ & $\begin{array}{l}\text { Partially } \\
\text { correct } \\
\mathrm{n}(\%)\end{array}$ & \\
\hline $\begin{array}{l}\text { What is the causative organism } \\
\text { of Corona infection? }\end{array}$ & $30(15.2)$ & & $167(84.8)$ \\
\hline $\begin{array}{l}\text { What is the reservoir of coronavi- } \\
\text { rus infection? }\end{array}$ & $9(4.22)$ & $95(44.8)$ & $108(50.9)$ \\
\hline $\begin{array}{l}\text { What is the incubation period of } \\
\text { coronavirus in a human being? }\end{array}$ & $43(18.6)$ & & $177(80.5)$ \\
\hline $\begin{array}{l}\text { How COVID- } 19 \text { disease manifests } \\
\text { in human beings? }\end{array}$ & $7(3.2)$ & & $212(96.8)$ \\
\hline $\begin{array}{l}\text { How to confirm the diagnosis of } \\
\text { Coronavirus infection? }\end{array}$ & $116(51.8)$ & & 104(47.3) \\
\hline $\begin{array}{l}\text { Which group of patients will have } \\
\text { serious illness after COVID-19 } \\
\text { infection? }\end{array}$ & $1(0.5)$ & $45(20.8)$ & $170(78.7)$ \\
\hline $\begin{array}{l}\text { Do most of the coronavirus infec- } \\
\text { tion recover? }\end{array}$ & $3(1.4)$ & & 217(98.6) \\
\hline $\begin{array}{l}\text { What is the size of the corona- } \\
\text { virus? }\end{array}$ & $135(65.5)$ & & $71(34.5)$ \\
\hline $\begin{array}{l}\text { What is the sequence of corona- } \\
\text { virus virion? }\end{array}$ & 109(51.7) & & $102(48.3)$ \\
\hline $\begin{array}{l}\text { What is the present percentage } \\
\text { of human death after coronavirus } \\
\text { infection worldwide? }\end{array}$ & 109(52.4) & & $99(47.6)$ \\
\hline $\begin{array}{l}\text { How Coronavirus is primarily } \\
\text { transmitted in human beings }\end{array}$ & $41(20)$ & $9(4.4)$ & $155(75.6)$ \\
\hline $\begin{array}{l}\text { Do we have a vaccine for corona } \\
\text { infection at present? }\end{array}$ & $19(9.3)$ & & 186(90.7) \\
\hline Attitude & $\begin{array}{l}\text { Negative } \\
\text { Attitude } \\
\mathrm{n}(\%)\end{array}$ & & $\begin{array}{l}\text { Positive } \\
\text { Attitude } \\
\text { n (\%) }\end{array}$ \\
\hline $\begin{array}{l}\text { Do you use of } \mathrm{N} 95 \text { mask while } \\
\text { performing aerosol procedures? }\end{array}$ & $89(42.8)$ & & $119(57.2)$ \\
\hline $\begin{array}{l}\text { Do you hand wash before taking } \\
\text { care of patients? }\end{array}$ & $28(13.1)$ & & $186(86.9)$ \\
\hline $\begin{array}{l}\text { Do you hand wash after taking } \\
\text { care of patients? }\end{array}$ & $10(4.7)$ & & 204(95.3) \\
\hline $\begin{array}{l}\text { Do you believe corona infection } \\
\text { is preventable? }\end{array}$ & $18(8.4)$ & & 196(91.6) \\
\hline $\begin{array}{l}\text { Are you afraid to take care of } \\
\text { fever patients? }\end{array}$ & $135(63.1)$ & & $79(36.9)$ \\
\hline $\begin{array}{l}\text { Are you afraid to take care of } \\
\text { respiratory infection cases? }\end{array}$ & $146(68.2)$ & & $68(30.9)$ \\
\hline $\begin{array}{l}\text { Are you afraid to go to public } \\
\text { places? }\end{array}$ & $176(82.6)$ & & $37(17.4)$ \\
\hline $\begin{array}{l}\text { Do you think today's condition } \\
\text { has a negative effect on the } \\
\text { economy of the country? }\end{array}$ & 206(96.7) & & $7(3.3)$ \\
\hline $\begin{array}{l}\text { Are you afraid that your family } \\
\text { members will get infected? }\end{array}$ & $200((93.9)$ & & $13(6.1)$ \\
\hline Practice & $\begin{array}{l}\text { Poor } \\
\text { Practice n } \\
(\%)\end{array}$ & & $\begin{array}{l}\text { Good } \\
\text { Practice } \\
\text { n (\%) }\end{array}$ \\
\hline Do you isolate suspected cases of & $24(11)$ & & 194(89) \\
\hline
\end{tabular}

\begin{tabular}{|c|c|c|}
\hline $\begin{array}{l}\text { How to prevent or slow the } \\
\text { transmission of COVID-19 infec- } \\
\text { tion? }\end{array}$ & $10(4.5)$ & 210(95.5) \\
\hline $\begin{array}{l}\text { Will you trace the close contact } \\
\text { of the confirmed case? }\end{array}$ & $46(22.2)$ & $161(77.8)$ \\
\hline Who should use surgical masks? & $16(7.3)$ & 204(92.7) \\
\hline
\end{tabular}

afraid to go to public places. Other common negative attitudes included being afraid of taking care of respiratory illness patients $(n=146)$ and taking care of fever patients $(n=135)$. Conversely, the majority of participants responded positively regarding their attitudes about wearing surgical masks $(n=204)$, hand washing after $(n=204)$ and before $(n=186)$ interacting with patients and believing corona infection is preventable $(n=196)$ (Table 2$)$.

In multivariate binary logistics analysis, participants with clinical experience level one to five years (adjusted OR: .42, $\mathrm{Cl}$ : 19-.96) and more than 5 years (adjusted OR: .16, Cl: .04.63) were significantly associated with a negative attitude. The confidence score for managing COVID-19 (OR: 1.16, $\mathrm{Cl}$ : 1.02-1.34) was significantly associated with a positive attitude score (Table 4).

\section{Practices}

The overall median practices score was 6 (IQR:1). A score 4 or above was considered "good" practice and scores below 4 considered "poor" practice. Most of the participants $(n=217,98.6 \%)$ reported good practices and only a few $(n=3,1.4 \%)$ reported poor practices. 210 participants $(95.6 \%)$ reported taking precautions while taking care of patients, wearing the surgical mask during work hours $(\mathrm{N}=204,92.7 \%)$ and isolating infected patients $(\mathrm{N}=194$, $89 \%$ ), while 46 participants (22.2\%) failed to trace the close contacts (Table 2). None of the independent variables was significantly associated with the practice score on logistic regression analysis ( $p>0.05)$.

The overall results of this study showed that most of the participants obtained good knowledge scores with good practice scores and negative attitudes. Knowledge score varied across gender, level of education and occupation whereas practice score was statistically correlated only with knowledge score $(p<0.001)$ (Table 3 and Table 5). Attitude score was statistically significant with the confidence scores $(p<0.05)$ and the clinical experience $(p<0.05)$ (Table 4 and Table 5) of the healthcare workers. The overall median confidence score of healthcare workers towards COVID-19 was 4 (IQR: 3).

\section{DISCUSSION}

This study provides significant insight into the knowledge, attitude and practices (KAP) among healthcare providers about COVID-19. Our study showed that two-thirds of the participants had good knowledge and almost all participants reported good practices related to COVID-19. The majority of the participants, however, report negative 
Table 3. Knowledge, attitude and practice scores of Health Workers in Dhulikhel Hospital

\begin{tabular}{|c|c|c|c|c|c|c|}
\hline Variables & $\begin{array}{c}\text { Knowledge }^{a} \\
(\operatorname{Max}=22)\end{array}$ & $\begin{array}{l}\text { Good knowledge } \\
n=151\end{array}$ & $\begin{array}{l}\text { Attitude }{ }^{b} \\
(\operatorname{Max}=10)\end{array}$ & $\begin{array}{l}\text { Positive Attitude } \\
n=87\end{array}$ & $\begin{array}{l}\text { Practice }^{c} \\
(\operatorname{Max}=6)\end{array}$ & $\begin{array}{l}\text { Good practice } \\
n=217\end{array}$ \\
\hline & $\begin{array}{l}\text { Mean } \pm S D \\
\text { Median } \pm I Q R\end{array}$ & Freq. (\%) & $\begin{array}{l}\text { Mean } \pm S D \\
\text { edian } \pm I Q R\end{array}$ & Freq. (\%) & $\begin{array}{l}\text { Mean } \pm S D \\
\text { Median } \pm I Q R\end{array}$ & Freq. (\%) \\
\hline Overall & $15 \pm 4$ & $151(68.6)$ & $5 \pm 2$ & $87(40.7)$ & $6 \pm 1$ & $217(98.5)$ \\
\hline \multicolumn{7}{|l|}{ Gender } \\
\hline Male & $16.69 \pm 2.55^{\wedge}$ & $42(91.3)^{*}$ & $5 \pm 3$ & $17(37)$ & $6 \pm 6$ & $46(100)$ \\
\hline Female & $14.68 \pm 3.0)^{\wedge}$ & $109(62.6)$ & $5 \pm 2$ & $70(41.7)$ & $6 \pm 1$ & 171(98.3) \\
\hline \multicolumn{7}{|l|}{ Age } \\
\hline$\geq 30$ & $15 \pm 4$ & $118(66.7)$ & $5 \pm 2$ & $73(42.7)$ & $6 \pm 1$ & 175(98.9) \\
\hline$>30$ & $15.22 \pm 2.85^{\wedge}$ & $33(76.7)$ & $5 \pm 2$ & $14(32.6)$ & $6 \pm 1$ & $42(97.7)$ \\
\hline \multicolumn{7}{|l|}{ Education } \\
\hline Certificate & $14.15 \pm 2.87^{\wedge}$ & $82(58.2)^{*}$ & $5 \pm 2$ & $55(40.7)$ & $5 \pm 1$ & 138(97.9) \\
\hline Bachelor & $16.59 \pm 2.74^{\wedge}$ & $39(84.8)$ & $5 \pm 3$ & $17(33)$ & $6 \pm 0$ & $46(100)$ \\
\hline Master & $17 \pm 3$ & $30(90.9)$ & $5 \pm 3$ & $15(45.5)$ & $6 \pm 0$ & $33(15.2)$ \\
\hline \multicolumn{7}{|l|}{ Occupation } \\
\hline Doctors & $17.11 \pm 2.33^{\wedge}$ & $56(91.8)^{*}$ & $5 \pm 3$ & $24(39.3)$ & $6 \pm 0$ & $61(100)$ \\
\hline Nurses & $14.34 \pm 2.94^{\wedge}$ & $78(59.1)$ & $5 \pm 2$ & $51(39.8)$ & $6 \pm 1$ & $130(98.5)$ \\
\hline Paramedics & $14.37 \pm 2.64^{\wedge}$ & $15(68.2)$ & $6 \pm 2$ & $10(50)$ & $5 \pm 1$ & $21(95.5)$ \\
\hline Technician & $13.2 \pm 2.33^{\wedge}$ & $2(40)$ & $5.2 \pm 1.3^{\wedge}$ & $2(40)$ & $4.8 \pm 0.37^{\wedge}$ & $5(100)$ \\
\hline \multicolumn{7}{|c|}{ Clinical experience } \\
\hline$<1$ year & $16 \pm 3.75$ & $40(76.9)$ & $6 \pm 3$ & $26(50)$ & $2 \pm 0$ & $51(98.1)$ \\
\hline $1-5$ years & $14.78 \pm 3.03^{\wedge}$ & $93(66.4)$ & $5 \pm 2$ & $53(39.6)$ & $2 \pm 0$ & 139(99.3) \\
\hline$>$ 5years & $14.64 \pm 3.3^{\wedge}$ & $18(64.3)$ & $4.85 \pm 1.40^{\wedge}$ & $8(28.6)$ & $2 \pm 0$ & $26(26.4)$ \\
\hline
\end{tabular}

Chi-square test was conducted. ${ }^{*}$ Statistically significant at $p$ value $<0.05$.

Abbreviations: Freq, frequency; IQR, interquartile range; max: maximum; SD, standard deviation.

^Mean \pm SD.

${ }^{a}$ Total score ranged from 0-22, A score of $\geq 14$ set for good knowledge and $<14$ for poor knowledge regarding COVID-19.

${ }^{\text {b}}$ Total score ranged from $0-10$. A score of $\geq 6$ considered as positive attitude and $<6$ for negative attitude.

'Total score ranged from $0-6$. A score of $\geq 4$ considered as good practice and $<4$ for poor practice.

\section{Table 4. Binary logistic analysis}

\begin{tabular}{|c|c|c|c|c|c|c|}
\hline Variables & OR & $95 \% \mathrm{Cl}$ & $p$-value & Adjusted OR & $95 \% \mathrm{Cl}$ & p-value \\
\hline \multicolumn{7}{|l|}{ Knowledge } \\
\hline \multicolumn{7}{|c|}{$\begin{array}{l}\text { Education } \\
\text { (reference: certificate level) }\end{array}$} \\
\hline Bachelor & 4.01 & $1.68-9.58$ & $0.002^{*}$ & $1.719^{\wedge}$ & $.53-5.52$ & .36 \\
\hline Master & 7.19 & $2.10-24.69$ & $0.002^{*}$ & $2.249^{\wedge}$ & $.29-17.39$ & .44 \\
\hline \multicolumn{7}{|l|}{$\begin{array}{l}\text { Occupation } \\
\text { (reference: technician) }\end{array}$} \\
\hline Doctors & 16.8 & $2.25-12.32$ & $0.006^{*}$ & $6.67^{\wedge}$ & $.49-91.15$ & .15 \\
\hline \multicolumn{7}{|l|}{ Attitude } \\
\hline Confidence & 1.16 & $1.03-1.32$ & $.017^{*}$ & $1.16^{\#}$ & $1.02-1.34$ & $.027^{*}$ \\
\hline \multicolumn{7}{|c|}{$\begin{array}{l}\text { Clinical experience } \\
\text { (reference: less than } 1 \text { year) }\end{array}$} \\
\hline Experience $1-5$ years & .65 & $.34-1.25$ & .20 & $.42^{\#}$ & $.19-.96$ & $.039^{*}$ \\
\hline Experience $>5$ years & .40 & $.15-1.1$ & 0.07 & $.16^{\#}$ & $.04-.63$ & $.009^{*}$ \\
\hline
\end{tabular}

*Statistically significant at $\mathrm{p}$-value $<0.05$

^Adjusted variables of knowledge (good knowledge vs poor knowledge) were age, clinical experience, level of education, gender, occupation, practice, attitude and confidence score.

"Adjusted variables of attitude (positive attitude vs negative attitude) were age, clinical experience, level of education, gender, occupation, knowledge, practice and confidence score. 
Table 5. Spearman rank correlation between knowledge, attitude, practice and confidence score

\begin{tabular}{|llll|}
\hline Variables & $\begin{array}{c}\text { Knowledge } \\
\text { Correlation } \\
\text { Coefficient }\end{array}$ & $\begin{array}{l}\text { Attitude } \\
\text { Correlation } \\
\text { Coefficient }\end{array}$ & $\begin{array}{l}\text { Practice } \\
\text { Correlation } \\
\text { Coefficient }\end{array}$ \\
\hline Knowledge & & -0.007 & $0.220^{* *}$ \\
\hline Attitude & 0.007 & & -0.076 \\
\hline Practice & $0.220^{* *}$ & -.076 & \\
\hline Confidence & 0.078 & $0.170^{*}$ & -0.058 \\
\hline
\end{tabular}

"Correlation is significant at the level of 0.05 ; ${ }^{* *}$ Correlation is significant at the 0.01 level.

attitudes towards COVID-19.

We observed that more than two-thirds of health care workers had good knowledge about COVID-19 which is consistent with other studies..$^{11,20,21}$ Health care workers demonstrated good knowledge about the basics of COVID-19, such as its causative agent, the disease manifestation, incubation period, transmission, and prevention but there was a lack of in-depth knowledge about the virus, especially among the lower-level health care workers. This finding is consistent with a study among health care workers in Pakistan by Saqalian et al. ${ }^{22}$

More than half of the respondents in our study were female and had received a certificate level of education. This is significantly different from a similar study conducted in China about COVID-19 where most of the participants had received higher levels of education. ${ }^{11}$ This could be responsible for the discrepancy in the results. In this study, better knowledge was found among doctors and the participants who had a bachelor's degree or higher which is consistent with other studies. ${ }^{20}$

We found that a good knowledge score was significantly associated with a good practice score. Participants with good knowledge scores reported performing preventive measures towards COVID-19 more than the participants with low knowledge scores. Other KAP studies on infectious diseases reported a similar association between knowledge and practice scores. ${ }^{23}$ In a study by Bao-Liang et al. higher COVID-19 knowledge scores were associated with a lower likelihood of potentially dangerous practices towards the COVID-19 pandemic. ${ }^{11}$

The main source of knowledge for healthcare personnel on COVID-19 was social media (26.45\%), a result consistent with a study from Pakistan. ${ }^{22}$ However, other studies reported that television and scientific journals also played a major role in delivering knowledge to healthcare workers while conducting a KAP study on influenza. ${ }^{24,25}$ This difference might be explained by the recent advancement of the internet and gained popularity on social media. ${ }^{26}$ Further, most of the training programmes were cancelled due to the outbreak and the government initiated a lockdown of the entire nation to decrease the spread of infection. ${ }^{27}$ Social media may not provide in-depth or accurate information and only highlights the problem which may not be enough for healthcare providers. ${ }^{28}$ Hence, health care workers should consult reliable sources such as guidelines and reports published by WHO, Centers for Disease Control (CDC) and ministry of health and population of Nepal to enhance the capacity of healthcare workers towards COVID-19.

In this study, more than half of the participants showed a negative attitude, a result consistent with the study on attitudes of Bangladesi people towards COVID-19. ${ }^{21}$ The negative attitudes were related to the impact of COVID-19 on Nepal's economy, fear of family members becoming infected and the fear of going to public places. Other KAP studies on middle east respiratory syndrome and COVID-19 also reported a negative impact on the economy, fear from catching infection by a family member, and fear of going to public places. ${ }^{29,30}$ Negative attitudes were mostly observed among experienced healthcare workers. This is possibly due to the fear of transmitting the disease to family members. These groups of people may be targeted for attitude improvement during overcoming COVID crises.

The finding of this study also suggests that the probability of participants falling in a positive attitude group increased with one unit increase in confidence score. This finding is consistent with a study which documented that attitudes are good predictors for consumer behaviours. ${ }^{31}$ Positive attitudes were reported about infection control measures like handwashing after patient interactions, wearing a surgical mask during work hours and hand washing after taking care of the patient. Healthcare workers have been practising these preventive measures for other infectious diseases also. ${ }^{30-32}$

Participants' confidence in managing COVID-19 patients positively correlated with their attitude scores and the healthcare workers in our study had low confidence in handling COVID-19. This might be due to the newness of the disease and paucity of literature on it. Even the use of personal protective equipment was overlooked and underutilized until recently. ${ }^{33}$ The confidence of COVID-19 patient management was unsatisfactory in a similar KAP study. ${ }^{19}$ Attitude scores did not differ statistically with age and gender similar to a study performed in Pakistani health care workers. ${ }^{22}$

The majority of healthcare workers $(98.6 \%)$ had good practices towards COVID-19, similar to the study by Zhou et al. $^{20}$ Since the infection prevention unit (even before the outbreak of COVID-19) trains health care workers about infection preventive measures inside the hospital, healthcare workers have retained safe practice behaviour through previous exposure to infectious diseases. Most of the participants had correctly practised infection preventive measures such as avoiding face touching, handwashing regularly and properly performing donning and doffing of personal protective equipment and wearing surgical masks. These practices have been practised in other infectious 
diseases too. ${ }^{32,34}$

We included participants who were going to be treating either suspected or confirmed COVID-19 patients. Thus, most of the participants were staff nurses. Hence, we speculate that knowledge and attitudes might be underestimated or practices might be overestimated. Lastly, this survey only represents one healthcare facility, and so the results may not be generalizable to other healthcare facilities within different healthcare contexts.

We analyzed the characteristics of KAP towards COVID-19 and identified several demographic factors associated with KAP; these findings are useful for public health policymakers and health workers for improving the prevention, management, and training opportunities related to COVID-19. The strength of the study lies in its sample recruited in the early phase of the epidemic in Nepal and reached people who do not have access to the internet and/or are not able to complete web-based surveys. It also recognizes target populations for COVID-19 prevention and health education programmes.

\section{CONCLUSION}

The results showed that healthcare workers report good knowledge and practices related to COVID-19. However, they lack optimistic attitudes and confidence. The findings also demonstrated that healthcare professionals seek information from unverified sources such as social media and co-workers. These results are impactful and should be addressed through standardized training opportunities and distribution of official sources about COVID-19 to healthcare professionals to deliver optimal care to COVID patients and to minimize the risk of transmission of infection among health workers. Constantly updated refresher training from authentic sources will contribute to better performance.

\section{ACKNOWLEDGEMENT}

The authors thank all of the participants involved in this study for their cooperation and support. Similarly, we would like to sincerely express gratitude to Ms. Sulekha Shrestha, Ms. Alisha Bade, Ms. Sharmila Shrestha, Ms. Jyotsana Twi Twi, Ms. Indira Shrestha from Dhulikhel Hospital, Ms. Sushma Dahal from Georgia State University, USA and Dr. Robin Man Karmacharya for providing various support.

\section{REFERENCES}

1. Cucinotta D, Vanelli M. WHO Declares COVID-19 a Pandemic. Acta Biomed. 2020; 91: 157-60.

2. Shrestha R, Shrestha $S$, Khanal P, et al. Nepal's first case of COVID-19 and public health response. J Travel Med; 27. Epub ahead of print. 18 May 2020. DOI: 10.1093/jtm/taaa024.

3. Fears of COVID-19 catastrophe as Nepal reports death from new Coronavirus, https://www.heraldopenaccess.us/ openaccess/ fears-of-covid-19-catastrophe-as-nepal-reports-death-from-newcoronavirus (accessed 25 July 2020).

4. Suleiman A, Bsisu I, Guzu H, et al. Preparedness of Frontline Doctors in Jordan Healthcare Facilities to COVID-19 Outbreak. Int J Environ Res Public Health. 2020; 17: 3181.

5. Powell-Jackson T, King JJC, Makungu C, et al. Infection prevention and control compliance in Tanzanian outpatient facilities: a crosssectional study with implications for the control of COVID-19. The Lancet Global Health. 2020; 8: e780.

6. Saint S, Ratz D. Improving Hand Hygiene Adherence in Healthcare Workers Before Patient Contact: A Multimodal Intervention in Four Tertiary Care Hospitals in Japan. Epub ahead of print 1 May 2020. DOI: 10.12788/jhm.3446.

7. Houghton $\mathrm{C}$, Meskell $\mathrm{P}$, Delaney $\mathrm{H}$, et al. Barriers and facilitators to healthcare workers' adherence with infection prevention and control (IPC) guidelines for respiratory infectious diseases: a rapid qualitative evidence synthesis. Cochrane Database Syst Rev. 2020; 4: CD013582.

8. Gershon RR, Zhi Q, Chin AF, et al. Adherence to Emergency Public Health Measures for Bioevents: Review of US Studies. Disaster Med Public Health Prep. 2018; 12: 528-35.

9. Zühlke LJ, Engel ME. The Importance of Awareness and Education in Prevention and Control of RHD. Glob Heart. 2013; 8: 235-9.

10. DiCuccio MH. The Relationship Between Patient Safety Culture and Patient Outcomes: A Systematic Review. J Patient Saf. 2015; 11: 13542.
11. Zhong B-L, Luo W, Li H-M, et al. Knowledge, attitudes, and practices towards COVID-19 among Chinese residents during the rapid rise period of the COVID-19 outbreak: a quick online cross-sectional survey. Int J Biol Sci. 2020; 16: 1745-52.

12. Bhagavathula AS, Aldhaleei WA, Rahmani J, et al. Knowledge and Perceptions of COVID-19 Among Health Care Workers: Cross-Sectional Study. JMIR Public Health Surveill. 2020; 6: e19160.

13. Sullivan KM, Dean AG, Mir RA. OpenEpi - Toolkit Shell for Developing New Applications, https://www.openepi.com/SampleSize/SSPropor. htm (accessed 21 June 2020).

14. Nour MO, Babalghith AO, Natto HA, et al. Raising awareness of health care providers about MERSCoV infection in public hospitals in Mecca, Saudi Arabia. East Mediterr Health J. 2017; 23: 534-42.

15. Alsahafi A, Cheng A. Knowledge, Attitudes and Behaviours of Healthcare Workers in the Kingdom of Saudi Arabia to MERS Coronavirus and Other Emerging Infectious Diseases. International Journal of Environmental Research and Public Health. 2016; 13: 1214.

16. http://edcd.gov.np/news/download/key-actions-to-be-taken-forncov-infection (accessed 29 July 2020).

17. CDC. Coronavirus Disease 2019 (COVID-19). Centers for Disease Control and Prevention, https://www.cdc.gov/coronavirus/2019ncov/hcp/clinical-guidance-management-patients.html accessed 29 July 2020).

18. Website, http://edcd.gov.np/news/download/key-actions-to-betaken-for-ncov-infection (accessed 29 July 2020).

19. Hussain A, Garima T, Singh BM, et al. Knowledge, attitudes, and practices towards COVID-19 among Nepalese Residents: A quick online cross-sectional survey. Asian Journal of Medical Sciences. 2020;11:6-11.

20. Zhou $M$, Tang $F$, Wang $Y$, et al. Knowledge, attitude and practice regarding COVID-19 among health care workers in Henan, China. J Hosp Infect. Epub ahead of print 9 April 2020. DOI: 10.1016/j. jhin.2020.04.012. 
21. Haque T, Hossain KM, Bhuiyan MMR, et al. Knowledge, attitude and practices (KAP) towards COVID-19 and assessment of risks of infection by SARS-CoV-2 among the Bangladeshi population: An online cross sectional survey. In Review.

22. Saqlain M, Munir MM, Rehman SU, et al. Knowledge, attitude, practice and perceived barriers among healthcare professionals regarding COVID-19: A Cross-sectional survey from Pakistan. J Hosp Infect. Epub ahead of print 8 May 2020. DOI: 10.1016/j.jhin.2020.05.007.

23. ul Haq N, Hassali MA, Shafie AA, et al. A cross sectional assessment of knowledge, attitude and practice towards Hepatitis B among healthy population of Quetta, Pakistan. BMC Public Health. 2012; 12: 692.

24. Albano L, Matuozzo A, Marinelli $P$, et al. Knowledge, attitudes and behaviour of hospital health-care workers regarding influenza A/ H1N1: a cross sectional survey. BMC Infect Dis. 2014; 14: 208.

25. Fatiregun AA, Olowookere SA, Oyebade AO. Pandemic Influenza A (H1N1): knowledge among senior health workers at a secondary health care institution in Southwest, Nigeria. Afr Health Sci. 2011; 11: 171-5.

26. Jensen JA, Ervin SM, Dittmore SW. Exploring the Factors Affecting Popularity in Social Media: A Case Study of Football Bowl Subdivision Head Coaches. Int J Sport Communication. 2014; 7: 261-78.

27. Rajbhandari B, Gurung M, Poudel L, et al. Probable Exit Strategy Against COVID-19 of Low Resource Country like Nepal: Open Floor Discussion. JNMA J Nepal Med Assoc. 2020; 58: 286-92.
28. Lau AYS, Gabarron E, Fernandez-Luque L, et al. Social media in health-what are the safety concerns for health consumers? Health Inf Manag. 2012; 41: 30-5.

29. Al-Amin FO, Alawneh SM. Knowledge, attitude and practices of healthcare providers towards MERS-CoV infection at Makkah hospitals, KSA. Int Res J Med Med Sci. 2015;3(4):103-12.

30. Azlan AA, Hamzah MR, Sern TJ, et al. Public knowledge, attitudes and practices towards COVID-19: A cross-sectional study in Malaysia. PLoS One. 2020; 15: e0233668.

31. Berger IE, Mitchell AA. The Effect of Advertising on Attitude Accessibility, Attitude Confidence, and the Attitude-Behavior Relationship. J Consum Res. 1989; 16: 269-79.

32. Cowling BJ, Zhou Y, Ip DKM, et al. Face masks to prevent transmission of influenza virus: a systematic review. Epidemiol Infect. 2010; 138: 449-56.

33. Liu $\mathrm{M}$, Cheng $\mathrm{S}-\mathrm{Z}, \mathrm{Xu} \mathrm{K}-\mathrm{W}$, et al. Use of personal protective equipment against coronavirus disease 2019 by healthcare professionals in Wuhan, China: cross sectional study. BMJ. 2020; 369: m2195.

34. Sadoh WE, Fawole AO, Sadoh $A E$, et al. Practice of universal precautions among healthcare workers. J Natl Med Assoc. 2006; 98: 722-6. 